\title{
Paradigmas administrativos, ética e intervenção do Estado na economia: o caso de Portugal
}

JOÃO BILHIM ${ }^{1}$

RICARDO RAMOS ${ }^{2}$

Luís Miguel PeREIRA ${ }^{3}$

\section{RESUMO}

Muita atenção tem sido dada na literatura administrativa e organizacional aos valores que guiam o comportamento organizacional e de gestão pública e privada. Todavia, o separador de águas entre a gestão pública e a privada manteve-se ao longo do tempo, com altos e baixos, como ponto controverso na literatura específica da administração e políticas públicas e do direito administrativo. A influência da Nova Gestão Pública (NGP) na reforma administrativa em Portugal é amplamente reconhecida em Portugal. Foram muitos os governos que,

1 Doutor e Professor Catedrático - Instituto Superior de Ciências Sociais e Políticas (iscsp) - Universidade de Lisboa (Ulisboa), Lisboa, Portugal. Fundador e pesquisador do Centro de Administração e Políticas Públicas (CAPP). Presidente da Comissão de Recrutamento e Seleção para a Administração Pública (CReSAP), Lisboa, Portugal. Correo-e: bilhim@iscsp. ulisboa.pt http://buscatextual.cnpq.br/buscatextual/visualizacv.do?id=K4383179T3

2 Doutor e professor associado, Instituto Superior de Ciências Sociais e Políticas (ISCSP), Universidade de Lisboa (Ulisboa), Portugal, Vice-Presidente do ISCSP/Ulisboa, Lisboa, Portugal.

3 Mestre em Gestão e Administração Pública pelo ISCSP-UL, Lisboa, Portugal. Correo-e: 1mpsoares@sapo.pt Fecha de recepción: 19 de agosto de 2015. Fecha de modificación: 4 de octubre de 2015. Fecha de aceptación: 15 de octubre de 2015. Para citar el artículo: BILHIM, J., RAmOS, R. y Pereira, L. M. (2015). Paradigmas administrativos, ética e intervenção do Estado na economia: o caso de Portugal. Revista Digital de Derecho Administrativo n. ${ }^{\circ} 14$, Universidad Externado de Colombia, pp. 91-125. DOI: http://dx.doi.org/10.18601/21452946. n 14.07 
nos países da $\mathrm{OECD}$, tomaram iniciativas idênticas. Há porém uma diferença acentuada entre a reforma administrativa dos países anglófonos e a dos países da Europa continental. Ora, tal diferença parece radicar no papel que o direito administrativo tem nestes países europeus e que não tem nos sistemas de Common Law. Este artigo quer contribuir para o debate da existência de dois paradigmas administrativos onde a separação entre gestão privada e pública parece colocar-se de forma diferenciada e a ética assume distinta ponderação.

Palavras-chave: paradigmas administrativos; administração privada e pública ${ }_{i}$ ética, economia.

\section{Paradigmas administrativos, ética e intervención del Estado en la economía: el caso de Portugal}

\section{RESUMEN}

Se ha prestado mucha atención en la literatura administrativa y organizacional a los valores que guían el comportamiento organizacional y de gestión pública y privada. Sin embargo, la separación entre la gestión pública y privada se mantiene con altibajos, a lo largo del tiempo, siendo un aspecto recurrente en la literatura específica de administración, políticas públicas y de derecho administrativo. La influencia que la Nueva Gestión Pública (NGP) tiene sobre la reforma administrativa es ampliamente reconocida en Portugal. Son muchos los gobiernos que, en los países de la OECD, han tomado iniciativas idénticas. De otra parte, existe una diferencia acentuada entre la reforma administrativa de los países anglosajones y la de los países de Europa continental. Ahora bien, dicha diferencia parece radicar en el papel que el derecho administrativo tiene en estos países europeos y que no tiene en los sistemas de Common Law.

Palabras clave: paradigmas administrativos, administración pública y privada, ética, economía.

\section{Administrative paradigms and the values of ethics: The case of Portugal}

\section{ABSTRACT}

Considerable attention has been given in administrative and organizational literature to the values that guide organizational behavior and public and private management. However, the separation between public and private management remains with its ups and downs and over time continues to be 
a recurring theme in literature specifically focused on management, public policy and administrative law. The influence that New Public Management (NPM) has had on Portugal's administrative reform has been widely recognized by Portuguese authors. In several OECD countries governments have taken similar initiatives. Nevertheless, there is a significant difference between the administrative reform found in countries of Anglo-Saxon heritage and the countries of continental Europe. Such a difference seems to be rooted in the role that administrative law plays in these European countries and the role it has in Common Law systems.

Keywords: Administrative paradigms, private and public Administration, Ethics, Economy.

\section{INTRODUÇÃO}

O objetivo deste trabalho é avaliar em que medida reformas oriundas do paradigma da common law - por exemplo a Nova Gestão Pública (NGP) -, pode obter sucesso quando aplicadas num país com valores culturais diferentes dos anglo-saxónicos como é o caso das administrações públicas da Europa Continental. Para tanto, tomou-se por campo de estudo duas reformas introduzidas em Portugal - uma sobre a ética do serviço público e outra sobre a intervenção do Estado na economia - e, com base no insucesso das mesmas, questiona-se a universalidade e a eficácia da receita da NGP quando aplicada acriticamente a países com raízes e valores culturais bem distintos dos que estiveram na origem daqueles onde nasceu esta nova corrente que desde os anos oitenta do século passado ameaçou invadir todo o mundo.

As questões que nortearam a pesquisa, foram as seguintes: por que razão a NGP não teve o sucesso nos países da Europa Continental que encontrou nos da common law? Por que razão os países da Europa Continental foram resilientes à cartilha anunciada pelos profetas da NGP nomeadamente às pressões da OCDE, do Banco Mundial e do Fundo Monetário Internacional? Por que razão em Portugal a reforma relativamente à ética do serviço pública começa e acaba com a publicação de um código de ética e nenhum Governo se preocupou com a gestão da implementação e da avaliação das práticas de gestão? Por que razão em Portugal a intervenção do Estado na economia não vai tão longe quanto foi nos países anglo-saxónicos e o Tribunal Constitucional, recusa a validação constitucional a um conjunto de políticas de natureza económica em uso nos países anglo-saxónicos? Por que razão os funcionários públicos, incluindo os dirigentes designados (não eleitos), apesar de cerca de trinta anos de retórica sobre reformas, preferem os valores da equidade à eficiência, este último mais próximos da administração privada? Por que razão para uns "administrar" é interpretar e aplicar a lei e para outros é melhorar permanentemente, (lei é um fim ou um meio)? 
Neste trabalho defende-se a existência de dois paradigmas administrativos distintos - Anglo-saxónico e Europeu Continental e critica-se a imposição de programa de reforma por organismo internacionais nomeadamente o FMI sem respeito pela tradição administrativa de cada país. Advoga-se que os movimentos de reforma da Administração têm não só de respeitar os valores culturais subjacentes aos distintos paradigmas por estarem a proceder à introdução simplesmente de técnicas e processos mas com elas estarem a produzir mudanças culturais mais profundas. É que os artefactos culturais visíveis expressam normas, valores e crenças mais profundas.

A metodologia de pesquisa seguida foi a qualitativa ligada ao estudo de caso que se caracteriza, como o próprio nome indica, pelo facto de a pesquisa se concentrar na seleção de um único caso em concreto. Nesta pesquisa não foi intenção submeter ao controlo empírico certas hipóteses, delas inferindo relações e assim produzir generalizações plausíveis (construção teórica) (Pasquino 2003). O recurso ao estudo de caso teve por fundamento a necessidade de proceder à validação post boc das teorias e para estudar o que nos pareceu casos desviantes (isto é, casos que parecem constituir uma exceção à regra) como parece ser o caso de Portugal e dos países inseridos no paradigma da Europa Continental.

Por isso, para compreender a Administração Pública Portuguesa atual é indispensável enquadrá-la historicamente entre dois paradigmas distintos - o europeu continental e o anglófono -, ou seja, entre o jurídico e o gestionário. O europeu continental acentuou-lhe a dimensão de instrumento de ação do Estado, e nessa medida a Administração Pública reflete o próprio Estado, enquanto a gestionária salienta-lhe a dimensão organizacional e de gestão de pessoas e meios para otimizar resultados destinados a satisfazer as necessidades coletivas.

Quando se compara a administração pública americana com a europeia, em especial a continental, consta-se que, neste último caso, o Estado é que modela a administração pública. Para (Pedrosa, 1908, p. 21) "o estudo da ciência da administração e do direito administrativo pressupõe o conhecimento da natureza do estado, porque o direito administrativo é norma reguladora da ação administrativa que o estado desenvolve no conseguimento de seus fins".

A administração pública é uma consequência que deriva dos princípios que fundam o Estado; assim o cameralismo (Bilhim, 2013, p. 33) é o tipo de administração intrinsecamente ligado ao "ancien régime", regime centralizado e absolutista, em que o poder estava concentrado nas mãos do monarca. Small (2009, p. 404) afirma que os cameralistas patenteiam uma conceção de estado unitário diferente de agregado. A sua teoria política era coletivista e secundariamente individualista. O Estado era tido como estando acima e sendo exterior ao cidadão, identificando-se com o governo que, por seu turno, seria a emanação do príncipe, que governa por direito divino. O Estado era visto como uma grande família proprietária de enorme quinta, cuja unidade estava 
simbolizada no príncipe. Havia uma espécie de unidade mística entre o príncipe o povo, podendo legitimamente colocar-se a questão de saber se era o Estado função dos cidadãos ou antes estes a função daquele.

$\mathrm{Na}$ Europa, o caso inglês constitui na Idade média um caso à parte. A Magna Carta, assinada por João Sem Terra no início do século XIII, representa uma garantia solene, reduzida a escrito, onde o monarca aceita a limitação e a repartição do poder político. É, de alguma forma, um compromisso, assumido num contexto medieval de reconhecidas desigualdades e assimetrias, tidas como "naturais", -coloca em causa o princípio da igualdade que vinha de Aristóteles-, que serviu para combater a emergência do absolutismo régio.

A Magna Carta é uma exceção na Europa que viu surgir o absolutismo régio e posteriormente no regime liberal foi governada por regimes mais ou menos totalitários. O rei medieval não estava acima do direito. O rei absoluto é que ficava acima das leis (principes a legibus soluto).

Ora, os EUA conhecendo a longa história europeia tomaram todas as medidas para evitar a concentração de poder. Aqui passa-se o contrário da Europa: é a administração pública que faz o Estado, o movimento aqui não é do topo para a base como na Europa, antes sobe da base para o topo da pirâmide. Os pensadores norte-americanos patenteiam uma conceção de estado agregado e não unitário, onde prevalece o individualismo ao coletivismo. O confronto entre os defensores de Jefferson e de Hamilton sobre os poderes dos estados americanos ou da federação revela bem esta natureza da administração pública americana criada para resolver problemas coletivos e não tanto como consequência da aplicação de princípios teóricos sobre o Estado (Stillman, 1997).

Acontece que, tanto antes quanto após 1948, a reflexão sobre estado não assumiu papel central nos EUA. Os manuais de estudo norte-americanos sobre a temática intitulavam-se simplesmente de Administração Pública evitando termos como a administração estadual ou o governo e administração entre outras designações. Tais são os casos paradigmáticos dos dois primeiros manuais publicados sobre administração pública nos EUA por White (1926) e Willoughby (1927).

Nos EUA, a teoria da administração pública anda à volta de cinco grandes temas: a separação entre quem decide e quem executa ${ }_{i}$ a dicotomia entre política e administração; a crença nas capacidades científicas, ao jeito positivista, da ciência da administração pública, a existência de um conjunto de princípios sobre a melhor maneira de organizar e gerir o trabalho; a eficiência e a economia como valores centrais da administração; a dicotomia entre o administrador honesto (ética) e o eficiente (mérito). Tudo questões que ao longo deste trabalho iremos aprofundar. 


\section{A ADMINISTRAÇÃO PÚBLICA ANGLO-SAXÓNICA \\ E A EUROPEIA CONTINENTAL: A EXISTÊNCIA \\ DE DOIS PARADIGMAS}

\section{EUA E A PERSPETIVA GESTIONÁRIA}

A perspetiva norte-americana era bem pragmática desde o início da fundação do Estado, procurando descobrir, e pôr em marcha, métodos mais racionais e eficazes destinados a resolver problemas concretos de um Estado novo que tinha tudo por fazer e sabia que não queria imitar o tipo de estado e de administração que conhecia na Europa. Nos EUA não se estuda a arte de governar: governa-se.

Conforme reconhecia Wilson (1887, p. 9), do lado americano do Atlântico Norte, onde havia espaço para empregos remunerados para todos, com princípios liberais de governo e capacidade ilimitada na política prática não sentiram a necessidade de cuidar de planos e métodos de administração, praticaram-na. Em sua perspetiva os governantes não são propriamente senão os servidores (servants) dos governados.

A sua principal preocupação é como evitar a corrupção e o abuso do poder político, ou seja como fomentar comportamentos éticos, construindo uma boa governação (good governement) que fosse digna de confiança, honesta, responsável e eficiente. É para resolver este problema que o Wilson vai beber de seus professores - Herbert Adamas e Richard Ely -, ambos doutores por Heidelbergue, a dicotomia entre política e administração por, em seu entender, esta separação permitir criar um grupo de profissionais capazes de fazer frente ao mal do tempo de que sofriam os políticos, o mal da corrupção, consequência da enorme expansão económica dos finais do século XIX.

Wilson, em 1887 na sua obra The Study of Public Administration, reproduzido em 1941 na revista norte-americana Political Science Quarterly, reconhece que a ciência da administração, em sentido estrito, ou seja, ciência da administração pública fora desenvolvida por professores alemães e franceses tendo sido adaptada às necessidades de um Estado compacto e feita à medida para formas altamente centralizadas de governo. Acrescenta no seu escrito que essa administração para a tender aos propósitos norte-americanos do final do século XIX deve ser adaptada para um complexo e multiforme Estado, feita sob medida para formas altamente descentralizadas de governo.

Para o pai fundador da Ciência da Administração nos EUA, se têm de usar esta ciência, então: "we must Americanize it, and that not formally, in language merely, but radically, in thought, principle, and aim as well. It must learn our constitutions by heart; must get the bureaucratic fever out of its veins; must inhale much free American air" (Wilson, 1887).

$\mathrm{O}$ autor esclarece que prefere que a América não tenha a história da Prússia nem o seu sufocante sistema de administração, mas gostava que tivesse a habi- 
lidade administrativa da Prússia. Aliás, acrescenta que é melhor ser destreinado e livre do que ser servil e sistemático. Contudo, não há que negar que seria ainda melhor ser, ao mesmo tempo, livre em espírito e proficiente na prática.

Quais eram os princípios essenciais da doutrina norte-americana até à segunda Guerra Mundial em matéria de administração pública? Quatro grandes princípios. O primeiro considera o processo de governo separado entre duas grandes parte - decisão e execução. Num primeiro momento, importava saber o que deve ser feito e esse empreendimento competia aos políticos e num segundo momento saber como executar, "getting things done" cabendo tal tarefa aos administradores.

Esta dicotomia, expressa por Woodrow Wilson, mas oriunda da Alemanha em particular da pena de Johann Bluntschli e de Lorenz Von Stein, militava a favor daqueles que queriam encontrar um espaço para afirmar a sua profissão, concedendo-lhes legitimidade para a emergência de um corpo permanente de profissionais treinados cientificamente no trabalho administrativo, selecionados e promovidos com base no mérito (Rosser, 2010).

Esta dicotomia política/administração permitia aos administradores ganhar poder e margem de manobra sobre os políticos. Os largos planos de ação governamental não são administrativos; a sua execução detalhada é administrativa. $\mathrm{O}$ administrador deve ter e tem uma vontade própria na escolha dos meios para efetuar o seu trabalho. Ela não é nem deve ser um mero instrumento passivo. A distinção é entre planos gerais e meios específicos. Se a administração é uma função distinta da política, então não deve ser permitida a interferência dos políticos na administração. "[T] hat administration lies outside the proper sphere of politics. Administrative questions are not political questions" (Wilson, 1887, p. 14).

Mas, por outro lado, a administração posiciona-se muito acima do nível monótono do mero pormenor técnico conquanto, através dos seus princípios, a administração se associa às máximas duradouras da ciência política, às verdades permanentes do progresso político. Assim, o segundo princípio consistia na crença que a administração era uma ciência vista à maneira positivista, mimetizando as ciências naturais, em que os fenómenos sociais eram considerados "coisas". A independência alcançada com a separação ocorrida entre administração e política permitia à administração granjear o estatuto de ciência face à política. A administração pública torna-se uma ciência que imita as novas ciências que entram em cena. O objeto da ciência da administração é salvar os métodos executivos da confusão e do alto preço da experiência empírica, alicerçando-os profundamente em sólidos princípios.

Nesta perspetiva Wilson, criticou fortemente aqueles americanos que revelavam medo dos estudos comparativos na ciência da administração. Comparar a prática americana da administração pública com a francesas ou alemã não significava abdicar dos princípios republicanos ou capitular aos ideais monárquicos. $\mathrm{O}$ autor exemplifica esta diferença com a arte de afiar a faca de 
um facínora em que a aprendizagem de bem afiar a faca não se confundia com a utilização que o facínora e o homem bom dariam a essa mesma faca afiada.

Assim a ciência da administração americana tinha de aprender com exemplo oriundos da Europa de outros sistemas políticos bem diferentes do americano onde a soberania não residia na vontade popular e a opinião pública expressa pelo voto não detinha o pode que possuía nos EUA. Advertia que não se deveria temer o contágio; mas aprender com a Europa mesmo se esta não estimava a soberania popular como acontecia na América.

O terceiro princípio, na sua síntese inicial, a administração pública apresentase como um enunciado de princípios. Esta "ciência" tinha em vista a descoberta de tais princípios universais que governavam toda a administração um pouco à semelhança do que acontecia com os princípios do direito ou da física. $\mathrm{O}$ objeto do estudo administrativo é salvar os métodos executivos da confusão e do alto preço da experiência empírica, alicerçando-os profundamente em sólidos princípios (Wilson, 1887, p. 13). Acresce que os princípios de Administração de Bonnin não eram desconhecidos dos americanos.

Nesta perspetiva, os dados sobre administração eram o resultado de uma pesquisa e descoberta de princípios gerais que estavam subjacentes a toda a atividade administrativa. Tais dados/factos seriam coletados, analisados, correlacionados, terminando no enunciado de um princípio ou axioma, que corresponderia à verdade científica. Aliás, não tinha já, em 1910, Frederick Taylor demonstrado a existência da lei "best way" nos processos de trabalho, seguindo uma adequada metodologia científica? Se esta lei era válida para a administração privada por que razão não devia ser para a pública?

O quarto princípio essencial destes tempos prende-se com economia e eficiência que eram centrais no estudo da administração pública e por vezes ensinados como o único objetivo da administração. Selecionar boas pessoas para a Administração não era suficiente. É necessário que a Administração fosse conduzida de forma económica e eficiente.

Ora, estes objetivos apenas podem ser alcançados pelo estudo científico, e pela descoberta e aplicação de adequados princípios de administração. Neste ponto, salientava-se a dicotomia entre o administrador "honesto" com comportamento ético e o eficiente capaz de atingir objetivos ao menos custo, mantendo a qualidade. Para tanto será necessário enviar aos concursos para o serviço público homens perfeitamente preparados a enfrentar exames sobre conhecimentos técnicos. Um funcionalismo público tecnicamente instruído, cedo tornar-se-á indispensável (Wilson, 1887, p. 18).

A partir da segunda guerra mundial esta doutrina rígida dos primeiros cinquenta anos de administração norte-americana mudou significativamente. Enfraqueceu-se a dicotomia política/administração, fruto do trabalho de Herbert Simon (1948) e de D. Waldo (1948); a preocupação em transformar a administração pública numa ciência foi flexibilizada ${ }_{i}$ a ideia da administração pública ser constituída a partir de princípios gerais e universais foi quase 
abandonada; a economia e a eficiência continuaram a desempenhar um papel central mas agora mais pelo lado das boas práticas do que pelo da aplicação de princípios; as categorias através das quais se estudava a administração também foram alteradas ${ }^{4}$.

Em suma, apesar da reconhecida influência exercida pela teoria política orgânica oriunda da Alemanha - Johann Bluntschli e de Lorenz Von Stein sobre os EUA (Rosser, 2010) os fundadores americanos da administração pública conheciam, mas não imitavam os modelos alemãs e franceses, expoentes do pensamento europeu continental do tempo. Desconfiavam do seu organicismo, do seu darwinismo social, do absolutismo régio, da centralidade do Estado, do seu coletivismo que militava abertamente contra o seu individualismo. Reconheciam as duas diferentes tradições intelectuais - individualismo americano e o organicismo europeu continental.

Os americanos encaram a liberdade individual como a razão principal da organização política. A Ideia que trespassa as páginas dos principais autores norte-americanos é que os EUA, em matéria de ciência política, são mais fazedores que teorizadores do Estado. Exceção seja feita a Dwight Waldo (1948) que, após ter constatado, esta ausência de teorização sobre o Estado, nos seus trabalhos destinados ao doutoramento em Yale, vai publicar a sua obra-mestra precisamente sobre "The Administrative State", ou seja, recuperar a reflexão sobre o Estado, a partir do tipo de administração pública. O Estado norte-americano não é um estado "capitalista", "militar", "de bem-estar, "maternal" ou de "partidos", é um Estado Administrativo (Sillman, 1997).

\section{A PERSPETIVA ORGÂNICA E JURÍDICA DA EUROPA}

Se é discutível se Wilson quis mesmo estabelecer uma dicotomia entre política e administração ou afirmar a sua inseparabilidade, tendo-se servido desse conceito apenas para evitar o abuso do poder político na América através da construção de uma administração competente e eficaz, o que hoje parece ser certo é ter o pai fundador da administração pública americana tomado tal conceito do organicismo político alemão transmitido através dos seus professores, formados na Alemanha no final do século XIX (Rosser, 2010).

Não será admissível, porém, pensar que Wilson é a expressão do pensamento alemão. Aliás, ele nem frequentou estudos na Alemanha, embora ainda tivesse querido, nem apesar da sua atitude favorável aos benefícios dos estudos de administração comparada, reconhecia que a tradição intelectual europeia possuía raízes opostas à americana baseada na liberdade de ação de

4 LUTHER GULICK e LYNDALL URWICK divulgaram o célebre acrónimo POSDCORB - planning

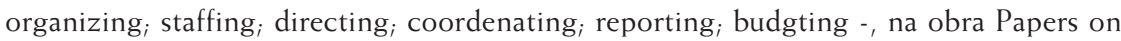
the Science of Administration. Ora, algumas destas categorias nunca mais abandonaram os manuais de Administração pública. 
cada indivíduo. A Europa ao contrário da América possuía uma tradição estatal. Aqui é o Estado que faz a administração e não ao contrário como aconteceu na América (Stillman, 1997). A Europa continental encara o Estado como o guardião da vontade comum. Para os europeus continentais o interesse público é um constructo que não se confunde com o interesse dos públicos/indivíduos.

Para Hegel (1990, p. 250), "A constituição política é, em primeiro lugar, a organização do Estado e o processo da sua vida orgânica em relação consigo mesmo. Neste processo distingue o Estado os seus elementos no interior de si mesmo e desenvolve-os em existência fixa". Para o filósofo, a separação de poderes de Montesquieu é importante, mas é preciso compreender que tal separação não pode passar de um princípio de distribuição de funções, não comprometendo a unidade soberana do Estado. É que para Hegel a divisão de poderes é uma desconcentração de funções estatais. Está subjacente no pensamento do autor a imagem de que o Estado é um concreto histórico, ser vivo onde há diferenciação de órgão e funções, que integram o todo. A separação de poderes instiga a sua independência, o que levado ao extremo traduzir-se-ia na dissolução do Estado como unidade orgânica, nesta perspetiva a monarquia é o elemento político consistente desse projeto.

É através da burocracia que o Estado se assume como realidade concreta e fornece aos seus membros serviços públicos, compondo, assim, "a vida social, que é concreta, ser governada de um modo concreto". A burocracia para o filósofo é a concretização da soberania que expressa nos funcionários do Estado; ela assume materialmente a existência do Estado como realidade concreta por um conjunto de funções e atribuições regulares em que apenas os funcionários podem exercer como representantes e expressão do próprio Estado.

Ora, Bluntchili na esteira deste organicismo da teoria política vai afirmar que a política, é a atividade do Estado "nas coisas grandes e universais" enquanto "a administração, por outro lado", é "a atividade do Estado nas coisas pequenas e individualizadas". A política é assim campo específico do estadista, a administração, do funcionário técnico". "A elaboração de diretrizes políticas não prescinde da ajuda da Administração"; mas nem por isso a Administração é Política.

Esta perspetiva do Estado e consequentemente a administração ser encarada à luz da metáfora orgânica, o conjunto dos cidadãos constituem um corpo um organismo vivo, com órgãos e funções diferenciadas e todas elas cooperando harmoniosamente para um fim comum a sobrevivência desse corpo. Assim, compreende-se que o Estado nesta tradição de pensamento possua personalidade jurídica enquanto tal instituto não fará qualquer sentido para uma tradição oposta como a da Common law.

Ora, na Europa continental do século XIX ao lado da perspetiva organicista alemã surge a perspetiva normativa e jurídica de Bonnin, grande admirador de Napoleão e construtor do seu modelo de administração. Segundo a conceção normativa ou jurídica, o objeto da ciência da administração é, apenas, a admi- 
nistração pública, considerada com uma instituição específica e diferente de outro tipo de organização. Nos países europeus é a ela que os juristas se referem e a mesma é objeto de estudo nas escolas de direito dos respetivos países. Em geral, os seus defensores não confundem "ciência da administração" com "direito administrativo", encarando a primeira como uma ciência positiva, e a segunda como uma ciência normativa.

$\mathrm{Na}$ Europa, com exceção da Inglaterra a perspetiva jurídica tem sido a abordagem marcante em todos os países do velho continente. A sua ligação está, claramente, patenteada no facto de se localizar nas faculdades de direito europeias uma cadeira ou um licenciatura com o nome de Ciência Administrativa ou Ciência de Administração.

Por outro lado, o imperativo do direito sobre a ciência da administração revela-se, ainda, no facto de desempenhar um papel importante nesta ciência, já que ocupa um capítulo onde se distingue a ciência da administração do direito administrativo. Este último, encarado como disciplina normativa, fundada sob os métodos da lógica formal, e a ciência da administração vista como disciplina positiva, que tem por objeto a administração tal e qual ela é. Apesar desta separação, em geral admitida, nem por isso a ciência da administração deixa de ser tributária dos esquemas do direito administrativo.

É, ainda, a partir de critérios de tipo administrativo, que se institui o próprio objeto da ciência da administração, ou seja, ela trata da administração pública, enquanto titular de um estatuto específico, e da sujeição a um regime jurídico que se afasta, e muito, do regime de direito comum.

Quanto aos estudos europeus sobre a Administração Pública verifica-se que andam associados à criação e ao desenvolvimento do Estado-Nação, saído do tratado de Vestefália - todo o Estado possui um território e nenhum pode interferir nos assuntos internos do outro - são os seus princípios basilares, hoje profundamente revisto pelo direito internacional.

Com a emergência do mercantilismo e do absolutismo régio a administração pública encontra no cameralismo desenvolvido na Prússia nos séculos XVII e XVIII a sua expressão mais fiel. O cameralismo representava uma espécie de "tecnologia administrativa", cujas técnicas e teorias foram desenvolvidas na Europa e sistematizadas entre meados do Século XVI e finais do século XVIII, em que o Estado foi concebido como entidade coletiva, orgânica e unitária (Small, 2009).

Entre as suas técnicas e teorias salientavam-se as atribuições e competências da polícia (ciência da polícia), a economia política e a ciência administrativa, assim como a eficiência da gestão da fazenda pública. Destacar o facto do valor da eficiência - um dos temas analisados neste artigo - já estar presente, pelo menos na sua parte tardia e final, do cameralismo. Acresce que o cameralismo vai sofrendo com o tempo um progressivo grau de abstração, abandonando a casuística que marcara a sua origem (Uribe). 
Com o liberalismo francês e Napoleão, é instituído um sistema administrativo de inspiração militar e restabelecido o sistema legal romano com a codificação das leis. Neste processo, Charles-Jean Bonnin vai desempenhar papel de destaque. Ele é o criador dos princípios da administração pública e, considerado, o fundador da moderna disciplina da administração pública na Europa (Vicher).

Para Bonnin (1812), autor do tratado Principes d'administration publique, a administração pública constituía uma atividade fixa e não episódica, positiva, uniforme e invariável e, consequentemente, uma ciência, abandonando a casuística que caraterizara o período anterior do cameralismo. Este tratado representou uma viragem nos conteúdos ensinados aos administradores do absolutismo régio - manuais de polícia-, e apresenta um grau de especialização tal que ultrapassou a economia política, contemplada pelo cameralismo.

Neste tratado dividido em doze partes principais, são esmiuçadas as atribuições e competências, assim como os processos administrativos que integram a chamada "organização administrativa". As normas a que se deveria submeter a administração, os procedimentos da justiça administrativa, os deveres dos administradores, o papel da estatística administrativa. A escola, nascida na França no primeiro quartel do século XIX, a partir do pensamento de Bonnin, firma-se no princípio da divisão dos poderes, considerando a administração como uma dependência do poder executivo ou uma das formas por que esse poder se manifesta. Em resumo, o conceito da administração deriva do estudo das atribuições do poder executivo.

Tudo indica que a influência de Bonnin não se fez sentir tardiamente em Portugal. De facto, é reconhecido por Marcelo Caetano (1994, p. 359), o papel decisivo que Bonnin desempenhou na reforma administrativa de Mouzinho Da Silveira promulgada a 16 de maio de 1832 . O mesmo administrativista português, num estudo sobre a codificação administrativa em Portugal, refere-se ao Decreto $n .^{\circ} 23$, de 16 de maio, de 1832 como pura e simplesmente decalcado da lei francesa de 28 do Pluviôse do ano VIII (1802), base da organização administrativa napoleónica.

Ora, se o impacto da revolução francesa se fez sentir de imediato na legiferação portuguesa pela ação dos liberais, a sua influência na universidade levou um pouco mais tempo. Para (Pedrosa, 1908, p. 8) "data portanto do ano letivo de 1853 a 1854, na faculdade de direito da Universidade de Coimbra, em cadeira própria, o ensino dos princípios de administração e do direito administrativo", seguindo os conteúdos dos Principes d'administration publique de Bonnin.

Para a antiga escola clássica, nascida na França no primeiro quartel do século XIX, e daí espalhada por toda a Europa, nomeadamente Portugal, a ciência da administração pública andava associada à ciência jurídica e em particular ao direito administrativo. Se para Bonnin o direito administrativo bastava por si para dar conhecimento de todas as matérias da administração pública, para Stein o direito administrativo devia ser desterrado e substituído por outras 
disciplinas tais como a das finanças, a do exército e a da administração propriamente dita -, por entender que a ideia da administração é dada pela ideia de estado operante.

A doutrina de Ferraris que assumia uma espécie de compromisso entre os dois extremos francês e alemão parece ter vingado até certo ponto na universidade portuguesa no pensamento de Pedrosa Guimarães. Todavia, na prática, quem é o vencedor é a antiga escola francesa, perspetiva normativa, que com ela deu início ao domínio do direito administrativo na administração pública portuguesa que dura até aos nossos dias e só recentemente foi posto em causa pela corrente da Nova Gestão Pública (NGP), portadora do paradigma anglosaxónico, perspetiva instrumental, assumindo as características do modelo do no novo estado weberiano (New) (Pollitt; Bouckaert, 2004, pp. 99-102).

Chegados a este ponto, fica claro que, de ambos os lados do Atlântico, ou melhor quer a Europa continental quer os países da common law, possuem administrações públicas diferentes em aspetos que não são apenas secundários. As suas diferenças são tão substanciais que podem caracterizar o que se entende por paradigmas científicos diferentes, em termos de ciência da administração pública. Com efeito para Thomas Kuhn (1970): um paradigma científico corresponde a um quadro que inclui todos os pontos de vista comumente aceites sobre um assunto, uma estrutura de pesquisa que impõe a direção a tomar e o caminho a seguir. É mais do que uma forma de pensar - é uma visão geral, uma crença ampla e profunda sobre que tipo de problemas vale a pena resolver ou que ainda são impossíveis de resolver. É um critério para selecionar problemas que podem ser assumidos como tendo solução num determinado quadro de pesquisa. Ora, é a existência de uma diferença profunda cujas raízes se prendem ao momento mais remoto da sua criação - o estado nação e a sociedade industrial - que está na base da existência destes dois paradigmas que atualmente nos confrontam.

\section{A ÉTICA}

Se entre o paradigma administrativo europeu continental e o da common law existe esta separação quanto ao tipo de administração como será que estes dois paradigmas colocam a questão da ética?

\section{A ÉTICA COMO CAMPO DE ESTUDO E ÁREA DE INTERVENÇÃO}

A ética na administração pública é estudada de vários ângulos. A partir dos fundamentos teórico-conceptuais que a estruturam e cuja expressão mais evidente está nas diferentes teorias éticas existentes (e nas possibilidades do seu ecletismo) que por sua vez determinam implicações distintas ao nível da ética aplicada e das configurações em termos de sistemas concretos. 
Outro ângulo de análise tem a ver com as suas incidências objetivas (ou não, na visão de alguns) mas sempre muito explícitas em casos limite como a corrupção ou situações dilemáticas. Veja-se a este propósito que a corrupção, enquanto fenómeno extremo e pungente da ausência de ética, tem um efeito ofuscante sobre outras situações, também elas não éticas e graves, como as disfuncionalidades organizacionais (Denhardt, 1988) tais como liderança autocrática, desvirtuamento na aplicação de instrumentos de gestão e na prossecução e definição de fins públicos (políticas públicas), injustiças resultantes de decisões tomadas em contextos mais discricionários e gestão não parcimoniosa da coisa pública, todos eles com impactos em termos de custos para a economia e para a despesa pública.

Num estudo encomendado pela OLAF (Organismo Europeu de Luta Antifraude) abrangendo 8 Estados membros da União Europeia e reportando-se a 5 setores de atividade (Infraestruturas Rodoferroviárias, Água e Tratamento de Resíduos; ${ }_{i}$ Construção de Infraestruturas Urbanas ${ }_{i}$ Formação e Investigação \& Desenvolvimento) estima-se que em 2010 os custos diretos com a corrupção ao nível dos processos de compras públicas naqueles setores se situou entre 1,4 e 2,2 biliões de Euros (OLAF, 2013).

Num outro documento de 2014 da OCDE (Organização para a Cooperação e Desenvolvimento Económico) é apontado que os custos globais da corrupção correspondem a pelo menos 5\% do PIB mundial (2,6 triliões de Dólares) sendo que todos os anos os valores estimados em subornos ascendem a 1 trilião de Dólares (OCDE, 2014).

Também o relatório de 2014 da Comissão Europeia sobre a corrupção indica que o seu custo corresponde a 120 biliões de Euros, quase o equivalente ao orçamento anual da União Europeia (Comissão Europeia, 2014).

Estas são incidências muitas vezes não percecionadas (ou não facilmente delimitáveis), situadas em zonas cinzentas e que derivam da falta de ferramentas integradas que as enquadrem. Ainda uma outra abordagem a este tema centrase na possibilidade (ou não) da sua "aplicabilidade prática", através do desenvolvimento de instrumentos e modelos para a implementação de uma ética organizacional e comportamental, onde, na ausência de medidas concretas, quantificadas, com efeitos práticos e implementadas, apresenta como aspeto mais visível o seu carácter muitas vezes rotulado de meramente "prescritivo" ou de aspiração, e, portanto, sem consequências (modelo anglo-saxónico vs. modelo europeu continental).

$\mathrm{Na}$ verdade, todos estes elementos tematicamente agregadores estão interrelacionados. Mas, se este conjunto de aspetos constituem diferentes abordagens ao estudo da ética na administração pública, também não é menos verdade que, simultaneamente, representam algumas das suas grandes dificuldades, as quais se podem condensar no facto de ainda não estar suficientemente interiorizado o carácter imanente da ética em relação à administração pública e da sua consequente plausibilidade no que toca à sua efetivação e operaciona- 
lização e em como isso é até uma necessidade (Soares, 2008, p. 11). Existem, de facto, efeitos concretos da não consideração da ética como uma dimensão da administração pública. Nesse sentido, mesmo que se considere que a ética é, antes de mais nada, um caminho a seguir, ele, todavia, tem de ser efetivamente percorrido, e de forma constante.

Não obstante, sobre estes grandes ângulos que depois se desmultiplicam em temas específicos já muito trabalho se realizou, o que confere à ética aplicada à administração pública consistência como campo de estudo e, mais do que isso, como uma área concreta de intervenção.

A corroborar isto mesmo estão as iniciativas e os desenvolvimentos (teóricoconceptuais, de articulação institucional, de práticas de atuação e de ações executadas) levados a cabo por entidades como a ASPA (American Society for Public Administration), OCDE (Organização para a Cooperação e Desenvolvimento Económico), ONU (Organização das Nações Unidas), GRECO (Group of States Against Corruption), IAACA (International Association of Anti-Corruption Authorities) e o OLAF (Organismo Europeu de Luta Antifraude), assim como de organizações não-governamentais como a TI (Transparency International), que com o seu Corruption Perceptions Index e o Global Corruption Barometer deram todo um novo alcance a esta matéria, pela forma inovadora e comparativa de analisar o fenómeno da corrupção à escala mundial e de possibilitar o seu acesso de forma generalizada aos cidadãos. Por outro lado ainda, a quantidade de artigos publicados em revistas científicas vem também reforçar precisamente a sua criticidade e importância.

Aliás, em 2011 a PAR (Public Administration Review) num artigo sobre as tendências de investigação em administração pública e a organização e categorização temática dos conteúdos da PAR, vem revelar que a ética constitui uma das suas 21 áreas temáticas, definidas em função do $\mathrm{n}^{\circ}$ de artigos publicados (Raadschelders, Jos C. N.; Lee, Kwang-Hoon, 2011). Mais até do que isso, o tema da ética situa-se no top $10 \mathrm{em}$ termos de quantidade de conteúdos publicados.

Também a sua importância ao nível académico está bem patente no facto de que a ética faz parte integrante, como disciplina autónoma, nas estruturas curriculares de muitos cursos de Administração Pública. A título ilustrativo: Em Portugal - Universidade de Lisboa (ISCSP) ${ }_{i}$ Universidade de Aveiro; Uni-

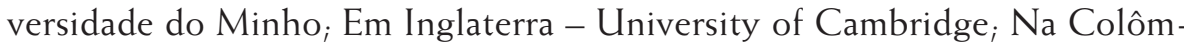
bia - Universidad Externado de Colombia (como tema integrado na cadeira de Gerencia pública, Maestría en Gobierno y Políticas Públicas), No Brasil: Universidade Federal Fluminense; Universidade Federal de Santa Catarina; Nos EUA - Harvard Kennedy School.

Compreende-se que assim seja, pois o que esta realidade evidencia é que a melhoria do desempenho global da administração pública é potenciado e induzido pela qualidade ética das decisões tomadas, que por sua vez têm de ser suportadas por uma política global e integrada para a sua efetivação. Tal só é possível através de determinação política e do desenvolvimento de ferra- 
mentas e metodologias coerentes e encadeadas que abranjam as pessoas e as organizações e que sejam implementadas consequentemente.

\section{2. ÉTICA E ECONOMIA: A MUDANÇA NECESSÁRIA}

Por isso, esta temática tem de ser abordada de uma forma integradora e não puramente legalista, estática, reparadora e/ou descritiva. Estas matérias foram até aqui essencialmente tratadas ou como assuntos de investigação criminal ou do âmbito do sistema de justiça ou das atividades inspetivas da administração pública, e pouco como temas a serem desenvolvidos ao nível organizacional, comportamental - isto é, no sentido gestionário/pragmático do modelo anglosaxónico -, da implementação no terreno de mecanismos que efetivem a ética, que previnam a ocorrência das situações complexas e que a desmistifiquem: como algo que não se fica pelo plano individual e subjetivo e, portanto, insuscetível de ser levado à prática (Soares, 2008).

Pois, se assim não for estaremos sempre perante os aspetos consumados da dimensão ética e sempre posicionados a jusante das ocorrências, do "mal" já feito e que muitas vezes não é reparável. Ora, é isto mesmo que com este contributo procuramos alterar. Portanto, o novo caminho a percorrer está na prevenção, na criação de sistemas dissuasores e de denúncia, de capacitação das pessoas e de efeitos concretos, por via da monitorização e articulação entre os vários sistemas, que necessariamente tem de ser mais dinâmica e não se confinar à simples observação da conformidade legal (Greco, 1996, p. 17).

É, então, ainda mais acutilante a discussão estruturada sobre esta matéria, de forma a concretizar o que propõe a OCDE, ou seja, evoluir do esquema conceptual dos habituais 3E (Economia, Eficiência e Eficácia), para uma situação inovadora, com a inclusão efetiva do E de Ética (OCDE, 1996, p. 60). Sobre isto, o que já sabemos é que é racionalmente mais evidente e aceite por todos a necessidade de nos orientarmos pelos $3 \mathrm{E}$. O que pode já não ser tão óbvio é o que a ética (E) pode acrescentar, em termos concretos. E esta é uma das suas dificuldades.

Assim, e de imediato, a ética acrescenta uma nova dimensão analítica para a resolução dos problemas. Na verdade, podemos encontrar uma faceta objetiva na ética e que tem paralelo com a administração pública, enquanto sistema que deriva dum Estado de direito democrático: é que ambas relacionam meios e fins.

Ora, esta relação meios/fins é avaliada do ponto de vista Económico (obter os recursos necessários ao melhor preço), da Eficiência (alcançar resultados com menos custos), da Eficácia (realizar os objetivos definidos) mas também da Ética (relação entre meios afetos e os fins estabelecidos e/ou alcançados: os fins justificam os meios?; relação entre fins definidos e sua articulação: que fins devem ser prosseguidos?; mas sobretudo, a clarificação dos seus fundamentos éticos: porque se prosseguem esses fins?). Diríamos mais, se a ética adiciona este tipo de análise ao modelo vigente $(3 \mathrm{E}+\mathrm{E})$, também é verdade que, se for 
perspetivada como o elemento em evidência, isso irá permitir analisar não só individualmente, mas sobretudo, conjugadamente, os outros $3 \mathrm{E}$, proporcionando, assim, uma avaliação e visão holística: $E(E+E+E)$.

Efetivamente, seja pela via das novas soluções, pelo avanço do conhecimento, pela maior perceção da dimensão ética ou pelas consequências de opções já tomadas, percebe-se que é imprescindível uma ética de ação. Em que é que isso se materializa? Pense-se, como $1^{\circ}$ exemplo, na forma como os serviços públicos são auditados/inspecionados: o trabalho que se faz a esse nível incide, sobretudo, na avaliação sobre a observância da "legalidade" formal das decisões. Ora, tem de se avaliar/escrutinar o seu mérito intrínseco, independentemente da observância da lei.

Trata-se de uma mudança de paradigma, no sentido da accountability: tem de se perguntar "porque foi assim decidido?" e não apenas "se a decisão respeita os requisitos legais?". E esta alteração, especialmente se enraizada, constitui uma manifestação da dimensão e efetivação da ética na administração pública e das suas vantagens. No fundo, esta mudança paradigmática traduz-se no seguinte: não basta pensarmos, de forma compartimentada, sobre quais são os fins definidos e como os concretizar (meios).

Temos de pensar não só em "quais são os fins?" mas, sobretudo, em "porquê estes fins?", tendo como subjacente uma integração ética de meios e de fins. A resposta a "quais são os fins?" é enumerativa. A resposta a "porquê estes fins?" obriga a uma reflexão e fundamentação ética mais profunda que torna evidente a dimensão ética da administração pública. Julgamos que por esta via é possível introduzir maior racionalidade e uma articulação otimizada entre os vários fins definidos e na forma de os alcançar (meios) (Soares, 2008, pp. 35-37; 107).

Esta mudança, podendo parecer muito teórica, permite, de um ponto de vista absolutamente pragmático e como $2^{\circ}$ exemplo, desta vez, ao nível das organizações e dos fins que têm de prosseguir e pelos quais foram criadas, trazer ao de cima sobreposições de áreas de atuação de diferentes instituições públicas, sobreposições essas que implicam sobre afetação de recursos (meios), dificuldades no alcance dos fins e consequentes implicações financeiras.

As repercussões finais do que acabámos de referir são sentidas pelos cidadãos, geralmente em impostos e desagrado no tratamento das situações em causa. Mas, o que estas disfuncionalidades orgânicas e interinstitucionais evidenciam é que, na verdade, não se deixou de responder à pergunta "quais os fins?" - uma vez que esses mesmos organismos foram criados com determinados fins conhecidos; ao que não se respondeu foi à pergunta "porquê estes fins?" porque se assim fosse a resposta contemplaria quem já os prossegue e evidenciaria o seu despropósito.

Neste sentido e como $3^{\circ}$ exemplo temos a dificuldade ou falta de cultura para o estabelecimento de "parcerias" de atuação pública que conduzem a uma obtenção de resultados percecionada como pouco eficaz, que não maximiza sinergias e recursos. Mostra-se, por isso, como necessário acelerar a lógica de 
integração de processos com foco nas necessidades específicas dos cidadãos, ainda que a sua prossecução seja da competência de entidades distintas. Um dos exemplos deste esforço na orientação para os cidadãos em Portugal é a "Loja do Cidadão", que inclui uma vasta "gama" de serviços e de disponibilização de informações on-line. Contudo, em muitas das situações, trata-se de serviços concentrados num mesmo edifício, e não tanto de integração de processos numa lógica de "balcão único".

Como exemplo final temos o peso das atividades autocentradas, isto é, voltadas para dentro da própria administração, muito associadas a funções de controlo e de prestação de serviços "internos". Muitas vezes nos questionamos, precisamente, no porquê da existência de algumas dessas entidades.

\section{A POLÍTICA ÉTICA COMO EFETIVAÇÃO DA ÉTICA NA ADMINISTRAÇÃO PÚBLICA}

Na perspetiva Anglo-saxónica, a ética mais do que uma nova metodologia para dirigir as instituições públicas ou um inovador modelo de gestão, a ética constitui uma sua verdadeira dimensão. Tal radica no facto de a administração pública ser um instrumento operativo do Estado, entendido este como "a forma mais perfeita de organização e convivência humana, pressupondo uma série de compromissos, que visando a satisfação das necessidades da sociedade, têm como base um conjunto de aspirações e desejos comuns, garantido dessa forma a paz social e até emocional. Deste modo, a dimensão ética não é apenas mais um conceito ou perspetiva, mas antes uma condição imanente que decorre da própria ideia e existência do Estado enquanto produção humana" (Soares, 2008, p. 12).

A efetivação e operacionalização da ética estão assentes na elaboração de uma política global, integrada e consequente que designamos de "política ética". De outra forma não poderia ser, pois já é suficientemente claro que a implementação de medidas desgarradas, ainda que em si mesmas sejam bem formuladas e concebidas não se mostra muito eficaz. Os códigos de conduta são um bom exemplo disto mesmo, que quando utilizados de forma isolada são meramente um conjunto de disposições.

Outro exemplo é a implementação mal estruturada de mecanismos de denúncia de más-práticas, que acabam por ter o feito exatamente oposto ao desejado. Assim, a "política ética" (Soares, 2008, pp. 113-128) (OCDE 1996) é constituída por 5 fases, que por serem integradas e encadeadas, lhe conferem consistência intrínseca. É, então, necessário caminhar no sentido da conjugação do maior pendor prático do modelo anglo-saxónico com a efetivação da ética e da sua assunção como dimensão da administração pública. Deste modo, a $1^{\text {a }}$ fase ou se quisermos, a pedra angular deste sistema, que constitui a sua fonte de ignição e a legitimação de toda a "política ética", reside num claro e absoluto empenho e compromisso político por parte dos Governos, pois é 
deles que depende a iniciativa e a força para a implementação das políticas, de preferência, através de uma comunhão de esforços e entendimento alargado.

Paralela e consequentemente têm de se aferir e determinar qual o grau de adesão e sensibilização para a ética por parte dos dirigentes e líderes da administração pública, dado o seu papel referencial na condução das organizações e nas repercussões éticas das suas decisões e comportamentos, na própria cultura organizacional e sobretudo, no seu papel central para o sucesso das políticas definidas e até para a sua própria conceção.

Pois, todo o esforço para a efetividade da ética na administração pública será infrutífero se não houver uma estrutura dirigente e de liderança que, a esse nível, a possa colocar em prática, ou seja, operacionalizar. Este aspeto tem efeitos concretos e diretos ao nível, por exemplo, do recrutamento e seleção (a começar pelos cargos de direção superior), de que em Portugal a CRESAP (Comissão de Recrutamento e Seleção para a Administração Pública) é um bom exemplo em termos de modelo, pois a lógica implícita da meritocracia (Bilhim, 2014) assenta no binómio competência e virtudes (Soares, 2014, pp. 81-85). A $2^{a}$ fase da "política ética" corresponde à criação de um organismo ou estrutura de cúpula e autónoma, responsável pela condução e implementação da "política ética". Este modelo, defendido atualmente por muitos, tem como exemplo o OGE (United States Office of Government Ethics).

As competências de um organismo deste tipo seriam: a) estudo, diagnóstico e aprofundamento teórico-conceptual da dimensão ética da administração pública ${ }_{i}$ b) desenvolvimento de metodologias, estratégias e instrumentos para a implementação da ética, através da elaboração de programas de implementação globais e integrados $;$ c) articulação e relacionamento com todos os organismos da administração pública por forma a garantir a coerência, eficácia, transversalidade e complementaridade da "política ética"; d) análise prospetiva e identificação de eventuais situações dilemáticas; e) monitorização e acompanhamento da implementação da "política ética", através da criação de mecanismos de avaliação, de controlo e recolha e tratamento de denúncias de más práticas e f) definição de procedimentos ou enquadramentos sancionatórios, sem prejuízo dos normativos legais estabelecidos.

A $3^{a}$ fase consiste na monitorização-avaliação da operacionalização da "política ética". Trata-se de um aspeto crítico de qualquer sistema, pois é por via da medição dos efeitos das soluções postas em prática que se aquilata da sua eficácia e sucesso, podendo tomar-se medidas corretivas ou novas formulações, dado ser um processo permanentemente em curso. Esta monitorização é levada a cabo pelas instituições que correspondem ao descrito na $2^{\text {a }}$ fase e que têm como responsabilidade a coordenação e operacionalização da "política ética", devendo as suas conclusões ser apresentadas aos parlamentos. Esta fase pressupõe ainda uma articulação estreita com os organismos de inspeção/ fiscalização da administração pública, geralmente especializados por áreas de intervenção como as finanças, a saúde, educação, etc. e com os organismos 
ligados à investigação criminal, promoção e defesa da legalidade, exercício da ação penal e representação do Estado, Tribunais e o provedor (ombudsman).

Esta articulação mostra-se imprescindível, pois é natural que no decurso da operacionalização e monitorização da "política ética" (processos permanentes e sempre evolutivos) emirjam situações de tipo criminal ou de contornos legais pouco claros, nomeadamente, corrupção, peculato, etc. e que se enquadrem num tipo de ação com moldura legal predefinida. Deste modo, os efeitos da monitorização da ética que levantem este tipo de questões irão ser encaminhados e tratados no âmbito das respetivas entidades competentes. Sobre isto, os trabalhos da OCDE relativamente às realidades dos vários países evidenciam uma vertente de avaliação e monitorização da "política ética" - Assessment e uma outra de inspeção/fiscalização e investigação - Scrutinising Misconduct in the Public Service (OCDE, 2004).

A $4^{a}$ fase corresponde à designação de responsáveis ou à institucionalização formal de unidades orgânicas no seio das organizações da administração pública para a implementação e condução interna da "política ética" e das estratégias, medidas e instrumentos para a sua efetivação. Esta fase é fundamental para a agilização de todo o processo de operacionalização e monitorização da ética e também para garantir a articulação entre a entidade coordenadora da "política ética" ( $2^{a}$ fase) e todo o universo de organismos que compõem a administração pública. Este modelo é muito próximo do sistema americano, onde é designado um responsável pela efetivação da ética, em cada organismo da administração pública - Designated Agency Ethics Official, o qual constitui um elo de ligação com o OGE.

A $5^{\mathrm{a}}$ fase prende-se com o desenvolvimento de instrumentos e metodologias específicas, concebidas ao nível da estrutura ou entidade de coordenação da ética ( $2^{\text {a }}$ fase) e posteriormente implementadas pelas unidades orgânicas dos diversos organismos da administração ou pelos seus agentes nomeados. O necessário ajustamento e acompanhamento serão estabelecidos por via da ligação entre estes dois níveis de estruturas de efetivação da ética: por um lado, a entidade de cúpula responsável pela "política ética" (enquanto sistema global) e, por outro, as unidades orgânicas constituídas em cada uma das organizações da administração pública, responsáveis pela sua operacionalização e gestão interna.

Assim, como $1^{\circ}$ instrumento temos os códigos de conduta ou códigos éticos. Estes devem assumir um forte caráter prático de modo a que se possam constituir como uma ferramenta de trabalho que auxilie e oriente no exercício das funções, aos mais diversos níveis organizacionais. Por outro lado, não é só o aspeto funcional destes códigos que deve constituir a preocupação central. Para que seja efetivo, eficaz, e prático, como se referiu, também é necessária a sua divulgação e promoção, precisamente, como instrumento de trabalho e, sobretudo, ser inclusivo, ou seja, fazer participar de forma alargada todos 
os membros da organização no processo da sua elaboração, aspeto que deve estar subjacente à lógica de toda a sua conceção.

$\mathrm{O} 2^{\circ}$ instrumento reporta-se aos sistemas de denúncias de más práticas (whistleblowing). Este instrumento é muito importante, pois a efetividade da ética também passa pela possibilidade de se poder e/ou dever relatar situações que se configurem como inéticas e/ou ilegais e que afetam diretamente ou não quem as revela. Por isso, terão de ser robustos e bem estruturados de modo a induzir confiança e segurança a quem revela algo e, simultaneamente, a possibilidade de a informação poder ser recolhida, processada e validada quanto aos seus fundamentos de forma organizada e consequente, podendo transitar, caso se justifique, para a esfera de atuação das entidades de investigação criminal e promoção da legalidade, como referido na $3^{\text {a }}$ fase.

A razão de ser deste tipo de mecanismos prende-se com o facto óbvio de que a exposição de más práticas se afigura como um meio para a promoção da ética, de prevenção e inibição da corrupção e outros tipos de condutas inéticas e/ou ilegais e de transparência da administração pública. Assim, a salvaguarda dos interesses em causa, nomeadamente, daqueles que denunciam, da própria organização e até de quem é denunciado, dado o carácter de anonimato que muitas vezes se encontra associado a estes mecanismos como forma de proteção, são questões críticas a considerar. Esta realidade tem diversas implicações como o dever de lealdade para com as organizações e toda a estrutura hierárquica, de sigilo profissional, de solidariedade, de consciência pessoal, da imagem dos elementos envolvidos, das formas de fundamentação, de confidencialidade e de proteção da integridade moral e física dos denunciantes.

Por ser um mecanismo tão sensível deverá estar consagrado em forma de lei. Pode compreender vários níveis ou possibilidades para se procederem às denúncias, desde a própria organização sobre a qual a mesma incide, até aos organismos responsáveis pela coordenação da "política ética" ( $2^{a}$ fase) e organismos de promoção da legalidade e tribunais. Um $3^{\circ}$ instrumento relaciona-se com formação específica aos funcionários públicos sobre este tema.

Estas atividades formativas e de promoção da discussão e pensamento sobre a ética na administração pública, os valores pelos quais se norteia e a conduta por que se pauta devem ser permanentes e incrementais levando ao aprofundamento do conhecimento individual e "coletivo" acerca das incidências pessoais e organizacionais da ética.

Um bom exemplo de integração e coerência interna da "política ética" é o facto de que o próprio sistema se pode autoalimentar, pois, por exemplo, a elaboração dos códigos de conduta, ao pressupor a participação de todos, pode ter como embrião da sua análise, discussão e tratamento ao nível da sua abordagem teórico-conceptual as próprias sessões de formação em ética na administração pública. É então necessário desenvolver e potenciar nos vários níveis da administração pública (aqui se incluindo, obrigatoriamente, 
os dirigentes) as capacidades de raciocínio, discernimento e análise ética das situações complexas.

Nesse sentido, e como temas específicos surgem os dilemas éticos, a corrupção, as incidências das reformas operadas e de todo o processo transformacional por que passa a administração pública, a importância das virtudes a par das competências profissionais, a deontologia, etc.

O $4^{\circ}$ instrumento desta fase da "política ética" são os modelos de suporte à tomada de decisão. $\mathrm{Na}$ prática este instrumento liga-se com o anterior (por requerer treino e por ser uma formulação inovadora na prática e contexto da administração pública) e tem como vantagem o seu pendor prático e utilitário, pois permite enquadrar as situações concretas em esquemas conceptuais que possibilitam uma organização lógica e encadeada das implicações das situações em causa. No fundo, constitui uma metodologia analítica para a ponderação e antevisão das consequências das opções disponíveis em processos de tomada de decisão.

O seu modelo genérico é o seguinte: a) caracterização da situação em causa ${ }_{i}$ b) levantamento das suas implicações éticas ${ }_{i}$ c) identificação das consequências positivas e negativas e d) identificação dos princípios e valores em jogo. Por fim, o $5^{\circ}$ instrumento, a accountability. Genericamente, traduz-se numa vinculação às ações e decisões tomadas e inerente responsabilização, com apresentação documentada sobre: o que se decidiu ("quais são os fins?") e por que se decidiu ("porquê estes fins?") - o E de Ética, se se atingiram os resultados definidos - o E de Eficácia; otimização dos custos dos resultados alcançados - o E de Eficiência e se os recursos (meios) foram obtidos ao melhor preço - o E de Economia. No fundo trata-se de prestar contas de forma não encriptada, com apresentação de resultados claros e compreensíveis também para os cidadãos com clara relação dos resultados atingidos em função dos objetivos definidos, razão de ser das opções e decisões estratégicas tomadas e os custos e receitas envolvidos. Veja-se o exemplo dos Orçamento de Estado participativos (Orçamento do Cidadão).

A combinação do paradigma anglo-saxónico com a efetivação da ética e da sua assunção como dimensão da administração pública, nos moldes propostos, acaba por corporizar estes $4 \mathrm{E}$ que a OCDE preconiza.

A fechar este grupo de 5 fases para a efetivação da ética na administração pública está a participação e envolvimento dos cidadãos. A perscrutação pública tem-se acentuado, sobretudo devido à comunicação social e à exposição mais alargada da corrupção. Esta realidade intrincada exige uma nova e efetiva forma de atuação e de filosofia na organização da administração pública: os cidadãos têm de ter mecanismos que possibilitem a sua inserção e participação e ter conhecimento inequívoco dos resultados e do trabalho desenvolvido pelas instituições, assim como da afetação de recursos implicada. Essa informação tem de ser clara, sintética, transparente e compreensível por todos. É importante intensificar o caminho para uma integração de processos orientados para 
o serviço ao cidadão e para a ética, traduzida em exigência, transparência e efetividade de medidas e consequências.

Em suma, a perspetiva que aqui deixamos da ética do serviço público prende-se com a tradição anglo-saxónica que coloca o foco na prática ética e não tanto na publicação de códigos de ética e orientações deontológicas. A perspetiva normativa tem-se revelado de fraca importância por se concentrar "no que deve ser feito" e descurar a dimensão da implementação e avaliação dessa mudança comportamental em termos éticos.

Pelo contrário, a perspetiva gestionária mais positiva e interventiva ganha mais espaço e assume maior importância por se focalizar "no que atualmente é feito" tentando continuamente melhorar a situação presente. A perspetiva gestionária centra-se na gestão dos comportamentos éticos e no papel que os dirigentes desempenham na criação de uma cultura ética do serviço público, lançando mãos dos processos de socialização e de treinamento dos funcionários e dirigentes para atingir a mudança comportamental.

Acresce que, mesmo na perspetiva teórica das redes sociais, o Estado joga sempre um papel na sociedade que, quando este não é determinante (principal ator) é, pelo menos, de ator importante e em consequência disso, quanto mais ético for a prestação do serviço público mais ética haverá nos negócios e na economia em geral, dada a influência que o Estado exerce em todos os aspetos da vida em sociedade.

\section{O ESTADO E A ECONOMIA}

\section{AdMINISTRAÇÃO PÚBLICA E PRIVADA}

Nos pontos precedentes, discutimos a relação entre os dois diferentes paradigmas administrativos - Anglo-saxónico e Europeu Continental - com a ética do serviço público. Constatamos que para o Europeu Continental a publicação de uma norma jurídica é suficiente para que um Governo possa afirmar que introduziu uma determinada política, enquanto para o Anglo-saxónico a lei é justamente um meio e não um fim. Por isso não se pode aplicar modelos de reforma acriticamente em países com distintos paradigmas administrativos.

Agora discutiremos se o tipo de intervenção do Estado na economia não andará igualmente associado ao paradigma administrativo. Assim, interrogamonos - será que a administração pública se confunde pura e simplesmente com a administração privada? ${ }^{5}$

5 Neste trabalho vamos tomar como sinónimos as expressões "administração pública" e "gestão pública" porque o que nos preocupa mais é analisar o adjetivo "pública" e não tanto o substantivo "administração/gestão". 
Na literatura dos países da common law, há uma tendência maioritária para afirmar que as diferenças entre as duas administrações são mínimas e de detalhe a todos os níveis da cadeia hierárquica, embora haja quem sustente que "they are fundamentally alike in all unimportant respects" tal como acontece com Allison, citando Wallace Sayre, antigo diretor do curso de administração pública de Columbia University. (Nowell: 2009).

Na perspetiva anglo-saxónica, a administração é um instrumento racionalmente concebido para a realização de objetivos instrumentais. Esta perspetiva faz uso da teoria sistémica e o seu objetivo é a obtenção de eficácia, eficiência e economia organizacional (Bilhim, 2014, p. 21). Waldo (1955: 7) confirma esta perspetiva ao entender a gestão como "action intended to acbieve rational cooperation in an administrative system", ou seja, é uma ação humana intencional, propositada, logo racional, que passa pela cooperação de quem trabalha num determinado sistema administrativo ou organizacional.

Quando Waldo (1955, p. 8) se questiona sobre - "what is public administration? What qualities are signified by the adjective" -, será que o adjetivo público tem o significado usado na biologia para distinguir a espécie em relação ao género? Ora, a esta questão o autor, um dos mais reputados nos EUA do século passado, responde que se trata de uma questão difícil.

Na resposta a esta questão difícil mas crucial, podemos recorrer à ciência política e afirmar que o adjetivo público limita o âmbito de aplicação do termo administração, circunscrevendo-o apenas a certo de administração tal como a do Governo ou do Estado remetendo a sua intervenção para as áreas da soberania, da legitimidade, do bem-estar geral ou até do interesse público. Ora, nesta espécie de administração, deteta-se que há algo em comum como seja a presença de uma certa coerção que não se encontra da mesma forma na administração privada.

Outra maneira de abordar o problema é fazer como fez Allison (1992) tomar um caso tipicamente de administração privada e outro de administração pública e identificar as semelhanças e diferenças entre ambos, por exemplo, um CEO de uma empresa cotada na bolsa de Lisboa e o Presidente da Autoridade Central dos Serviços de Saúde (ACSS) do Ministério da Saúde em Portugal.

Para identificar as semelhanças basta lançar mão das oito funções do célebre acrónimo - POSDCORB - difundido por Gulick E Urwick (1937), já atrás referido ou dos trabalhos de Peter Drucker (1948) ou de Chester Barnard (1938) para concluir que o ato de administrar, nesta perspetiva, é claramente comum tanto ao setor privado, quer ao público, ou seja tanto ao CEO de uma empresa cotada na bolsa, quanto ao presidente da ACSS do Ministério da Saúde. Todos planeiam, organizam, administram recursos humanos, dirigem, coordenam, reportam eventos, e orçamentam a atividade (Nowell, 2009).

Para identificar as diferenças, será necessário encarar o ato de administrar por outro prisma nomeadamente identificando como é que em cada um destes dois administradores perspetiva, por exemplo as questões relativas: ao tempo 
(o curto e o longo prazo); à estratégia, tanto a envolvente interna, quanto a externa; duração dos mandatos; medida do mérito; constrangimentos do có-

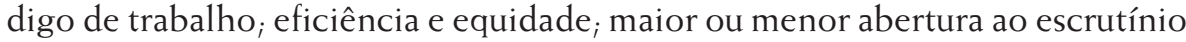
público, nomeadamente da comunicação social; impacto legislativo e judicial; papel do lucro ou da sobrevivência (Allison, 1992).

Na perspetiva da maioria dos autores anglo-saxónicos, estas diferenças são reduzidas à categoria de particularismos do sector público, embora não exista unanimidade acerca do grau de especificidade destes particularismos. Para uns, em termos abstratos e pensando nas oito funções da administração, a Administração Pública apresenta um conjunto de instrumentos de ação idênticos aos da gestão privada e, apenas, as escolhas estratégicas divergiriam, em razão dos diferentes objetos de estudo. Para outros, a gestão pública deve forjar instrumentos próprios de gestão e evitar qualquer imitação das empresas privadas.

Em suma, no paradigma anglo-saxónico a diferença entre administração pública ou privada reside na forma de valorar certos aspetos da administração, ou seja, em saber se são ou não importantes os aspetos (respects) em que as duas administrações são iguais. Ora, não há dúvida, que esta conceção se prende ao contexto sociopolítico bem característico que lhe subjaz - o desenvolvimento do conceito de "sociedade industrial" associado ao utilitarismo e ao individualismo americano.

Salienta-se que desde o início a administração pública americana estava preocupada com a perspetiva instrumental da eficiência, comum à administração privada. Para ser eficiente deve a administração descobrir os meios mais simples pelos quais a responsabilidade possa ser inequivocamente atribuída aos funcionários; a melhor maneira de dividir a autoridade sem prejudicá-la, e a responsabilidade, sem obscurecê-la. E esta questão da distribuição de autoridade, quando levada à esfera das mais altas e originárias funções de Governo, é obviamente uma questão central de Direito Constitucional. Ao contrário do que ocorre na Europa continental, Wilson (1887, pp. 360-361) interrogase: deve o funcionário esperar elogio e promoção do público ou somente de seu superior hierárquico? Deve o povo ser chamado a estabelecer a disciplina administrativa como é chamado a estabelecer princípios constitucionais? A resposta correta parece ser a de que a opinião pública deve desempenhar o papel de crítico autorizado.

No caso da Europa continental, a questão da administração pública e privada coloca-se em termos muito diferentes desta tradição da common law. Aqui é a construção do "estado nação" que está na base da administração pública e é nessa base que se poderá analisar esta relação. Para a Europa continental a administração pública é fundamentalmente normativa, fazendo depender da existência de norma jurídica o fazer, ou seja, se não há norma jurídica não se faz. Por isso, é que o n. 2 do artigo $266 .^{\circ}$ da Constituição da República Portuguesa determina que os órgãos e agentes administrativos estão subordinados à Constituição e à lei. 
Como já ficou claro em outro ponto deste trabalho, na Europa continental do século XIX, havia diferenças acentuadas entre o pensamento organicista alemão (Lorenz Stein e Johann Bluntschli) e o pensamento francês (Bonnin). Os pais fundadores americanos inspiraram-se fundamentalmente na tradição da common low britânica, mas conheciam as virtudes do pensamento organicista alemão apenas não lhe copiavam certos aspetos ortogonais à sua prática democrática com receio de poderem secundarizar o sagrado princípio da liberdade e pelo individualismo americano ser opor culturalmente ao organicismo alemão (Rosser, 2010).

Com efeito, o pensamento alemão está marcado pelo centralismo do estado e seu organicismo. Para Stein, a administração é um órgão vital do Estado que não está sujeito ao legislativo - a separação de poderes de Montesquieu não era aceite pacificamente - dado o ritmo gradual da legislação. A administração pode não ter de esperar pela lei para cumprir a vontade do Estado, dado que a lei é sempre uma consequência da experiência passada. Ora a administração por outro lado, está sempre em contacto com o presente: é o órgão estatal em ação e é por isso que ela é fonte de lei. Para o pensamento organicista alemão tanto o legislativo como o administrativo estavam comprometidos com a prossecução dos fins do Estado.

Para o pensamento organicista alemão a administração pública é a contínua e sistemática implementação de todas as atribuições e competências que competem ao Estado. A administração lida principalmente com os aspetos estruturais e os órgãos operativos da vida estatal.

Para Charles-Jean Bonnin a Administração pública não se expressa tanto como um órgão do Estado, mas antes expressa-se pelo seu sistema normativo. No prefácio à terceira edição dos Principes d'Administration Publique refere Bonnin (1832: XII): "je désirais convaincre ceux qui n'avaient jamais voulu voir dans l'administration qu'une conduite de routine et de circonstances, que l'administration peut et doit être réglée par des lois positives, des principes fixes, et être soumise à une marche uniforme et invariable".

Para o autor, as ideias de eficácia ou de relação entre a administração pública e privada estavam totalmente postas de parte. Com o pensamento francês inaugurou-se a perspetiva normativa do positivismo jurídico que marca a administração pública até aos nossos dias.

Nesta perspetiva se se pergunta ao funcionário público o que faz na Administração ele responderá que "interpreta e aplica a lei e o regulamento" em caso algum dirá que a lei é um meio para um fim que será instrumental, ou seja, a eficiência, eficácia e economia, numa curta expressão a melhoria contínua do serviço público. Esta corrente positivista milita abertamente, ao contrário do organicismo alemão contra a ideia de que a administração é a ação racional, entendida como ação corretamente calculada para realizar um determinado objetivo ou resultado. Ela é o resultado do cumprimento da lei e do regulamento. O "estado de direito" que esta perspetiva funda opõe-se assim ao "estado administrativo" que carateriza os EUA (Waldo, 1955, pp. 11, 12). 
Rivero (1980, p. 14) é bem expressão desta perspetiva normativa ao definir a administração como "L'activité par laquelle les autorités publiques pourvoient, en utilisant le cas échéant les prérogatives de la puissance publique, à la satisfaction des besoins d'intérêt public".

A força pública (puissance publique) mais não é do que o jus imperium que subjaz à distinção entre o contrato administrativo e o contrato comum ou seja a presença ou não da igualdade das partes. Em face disto, facilmente se entende que há uma dicotomia entre a administração privada e a pública. A administração pública está sujeita à lei especial o direito administrativo, enquanto a privada à lei comum na expressão do mesmo autor: "C'est ce que l'on exprime en parlant de l'autonomie du droit administratif, de son caractère dérogatoire au droit commun, et en opposant la gestion publique à la gestion privée de l'administration" (Rivero, 1980, p. 18).

Nesta perspetiva, a administração pública distingue-se da privada quanto aos fins e conteúdo. Com efeito, a administração pública tem por finalidade o interesse geral o interesse público e numa perspetiva mais filosófica o bem comum. Acontece que este interesse geral não é o interesse concreto de uma comunidade específica, mas de forma abstrata, um conjunto de necessidades humanas que não podem ser satisfeitas pelas simples regras do mercado. Variando com o tempo no seu conteúdo, o interesse geral não é suscetível de ser identificado por inquérito sobre as perceções sociais dos cidadãos. Ora a administração privada trataria precisamente do oposto, ou seja, trataria de bens e serviços de mercado e possuiria com finalidade o interesse individual, o luco, a quota de mercado ou uma vantagem sobre outrem.

Em suma, na Europa continental se ainda há possibilidade de estabelecer pontos de contacto entre a administração pública e privada no pensamento organicista alemão dada a ideia de eficiência, na perspetiva normativa positivista francesa os campos estão extremados sem pontos de contacto. Ora, todos os relatórios das organizações internacionais acusam o modelo europeu continental de ser mais permeável a comportamentos menos éticos pela opacidade da Administração e, consequentemente, menos eficazes o que acaba por prejudicar a economia. Para pagar as ineficiências da Administração recorre-se aos impostos, retirando dinheiro da economia real.

\section{A RELAÇÃo ESTADO/ECONOMIA}

Para tratar a questão da relação Estado/economia atualmente torna-se indispensável retroceder ao chamado Consenso de Washington onde esse domínio ficou patente.

Em 1989, reuniram-se em Washington, convocados pelo Institute for International Economics, diversos economistas latino-americanos de perfil liberal, funcionários do Fundo Monetário Internacional (FMI), Banco Mundial e Banco Interamericano de Desenvolvimento (BID) e do governo norte-americano. O 
tema do encontro foi "Latin American Adjustment: How Mucb bas Happened?". O encontro visava a avaliar as reformas económicas na América Latina.

No final desta reunião, coube a John Willianson (1990) o papel de elaborar os dez pontos consensuais que, com este gesto, acabou por cunhar a expressão "Consenso de Washington", através da qual ficaram conhecidas as conclusões daquele encontro, como regras universais: disciplina fiscal, redução dos gastos públicos ${ }_{i}$ reforma tributária ${ }_{i}$ juros de mercado ${ }_{i}$ câmbio de mercado: taxa de câmbio competitiva, abertura comercial, investimento estrangeiro direto; privatização, com a venda de empresas estatais; desregulação, com redução da legislação de controlo do processo económico e das relações trabalhistas; propriedade intelectual. Esta foi a cartilha imposta a todos os Estados.

Estas regras tinham como objetivo a expansão do papel dos mercados e a retração do papel dos Estados na economia. A partir deste momento, com Reagan como Presidente dos Estados Unidos e Margareth Tatcher, PrimeiraMinistra do reino Unido, máximas expressões do neoliberalismo em ação, deu-se início a um forte debate em torno das funções do Estado e da política de desenvolvimento económico.

A discussão à volta da redução do papel do Estado e da introdução dos valores e do espírito da gestão empresarial na Administração Pública vai beber a sua inspiração aqui nestas bases do Consenso de Washington. Mas agora Dani Rodrik, um reconhecido economista da Universidade de Harvard, foi a mais recente voz a questionar os fundamentos intelectuais do Consenso de Washington num convincente novo livro, intitulado One Economics, many recipes: Globalization, institutions, and economic growth. A tese de Rodrik é a de que, apesar de haver apenas uma economia, existem muitas receitas para assegurar o sucesso do desenvolvimento económico (Bilhim, 2014).

A tese das "muitas receitas" diz que os países se desenvolvem com êxito ao seguirem políticas ecléticas, feitas à medida, que respondem a condições locais específicas, em vez de seguirem fórmulas genéricas de melhores práticas concebidas por teóricos da economia. Esta perspetiva questiona as certezas do Consenso de Washington e a universalidade da sua receita quanto a mercados laborais, desregulamentação de setores de atividade, privatização, integração económica internacional, estabilidade macroeconómica e liberalização financeira.

Ora, a forma como o Estado tem encarado as falhas de mercado tem conduzido, desde o Consenso de Washington, à procura de alternativas e é nessa fase que nos encontramos. Os anos oitenta do século passado questionaram o papel do Estado na economia, tendo-se desde então iniciado um movimento de redução desse papel na vida económica e social. A conceção de um menor Estado, ou seja, de um menor protagonismo direto deste na atividade económica, apresenta tónicas diferenciadas entre si, desde versões minimalistas do tipo Estado mínimo, até versões mais intervencionistas, do tipo "intervir menos para intervir melhor" (Stiglitz, 1988, pp. 1-22). 
O Estado pode intervir na economia pelo menos através de diferentes formas: influência, regulação ex ante e ex post, mediação, distribuição, produção e planeamento. Ora, a modalidade que tem vindo a ser restringida é a de produção e as restantes têm em geral sido chamadas a um maior protagonismo.

A redução do peso do Estado-empresário e a liberalização de determinados sectores de atividade económica, a que se tem assistido em Portugal, têm sido acompanhadas por um alargamento do papel de Estado como regulador. É expressão disso a aprovação da Lei-quadro das entidades administrativas independentes com funções de regulação da atividade económica dos setores privado, público e cooperativo, Lei n. ${ }^{\circ} 67 / 2013$ de 28 de agosto.

As entidades reguladoras são pessoas coletivas de direito público, com a natureza de entidades administrativas independentes, com atribuições em matéria de regulação da atividade económica, de defesa dos serviços de interesse geral, de proteção dos direitos e interesses dos consumidores e de promoção e defesa da concorrência dos setores privado, público, cooperativo e social.

A Constituição da República Portuguesa (CRP), no seu art. ${ }^{\circ} 81^{\circ}$, alínea f), atribui ao Estado, sob a epígrafe "Incumbências Prioritárias", a obrigação de "assegurar o funcionamento eficiente dos mercados, de modo a garantir a equilibrada concorrência entre as empresas, a contrariar as formas de organizações monopolistas e a reprimir os abusos de posição dominante e outras práticas lesivas do interesse geral".

$\mathrm{Na}$ verdade, quer o funcionamento eficiente dos mercados, quer a concorrência equilibrada, quer ainda as formas de organização monopolistas, incluindo abusos de posição dominante e outras práticas lesivas do interesse geral, exigem do Estado uma melhor regulação. Em certo sentido, hoje, exige-se que o Estado converta parte dos recursos nomeadamente humanos que dedicava, tradicionalmente, à produção tangível de bens públicos em novas competências destinadas a satisfazer as novas atribuições da regulação.

A filosofia subjacente a este movimento de restrição do papel produtor e de expansão do poder regulador do Estado lança as suas raízes no paradigma da common law e em particular nos EUA onde o conceito de sociedade industrial, garantias das liberdades, individualismo e livre iniciativa são valores elevados acima dos restantes. No paradigma europeu continental quer na versão organicista quer na normativa francesa o Estado é sempre o principal ator quando não é apenas o único ator na rede de relações sociais.

Por isso, em nosso entender, esta alteração do papel do Estado na economia, que se registou após o chamado consenso de Washington, tem origem no paradigma da common law e novamente a forma como se está a expandir pelos diversos Estados é revelador de que o modelo europeu continental mais coletivo apoiado no conceito de Estado nação saído de Vestefália está a perder terreno. 


\section{CONCLUSÃO}

A reflexão feita até aqui permite concluir que, tanto a tradição da common law quanto a tradição europeia continental, correspondem a dois paradigmas no sentido que lhe atribuiu Thomas Kuhn. Acresce que, fruto da globalização, é o paradigma gestionário e instrumental da common law que parece ganhar terreno ao paradigma Europeu Continental na velha Europa e nos países que sofreram os efeitos da sua colonização. Por isso, em Portugal, presentemente, em matéria de reforma administrativa, sofre-se o efeito do confronto destas duas diferentes vagas ou paradigmas. A onda instrumental, da eficiência, eficácia, economia e ética do paradigma da common law e a maré normativa do positivismo jurídico francês. Tudo leva a crer que o modelo normativo virá a ser paulatinamente substituído pelo modelo da Nova Gestão Pública, embora salvaguardados alguns traços da sua tradição europeia continental o que conduzirá não tipicamente à Nova Gestão pública (NGP), mas antes ao chamado Novo Estado Weberiano (New).

Em segundo lugar, a questão da ética do serviço público é encarada em termos opostos nestes dois paradigmas. Na perspetiva da common law é preciso gerir os comportamentos éticos numa perspetiva da melhoria contínua. Pelo contrário, para a perspetiva europeia continental bastaria a publicação de um código e este por si faria o milagre da transformação organizacional e comportamental dos cidadãos e dos funcionários. Neste paradigma, tudo se resolve com a publicação de um ato normativo, nomeadamente um código de ética.

Em terceiro lugar, também parece ter ficado claro que no paradigma da common law há muito espaço para diálogo e terreno fértil para a aprendizagem mútua com trocas de boas práticas entre a administração pública e a privadas, porquanto ambas nascem da noção de sociedade industrial.

No que tange ao paradigma Europeu continental, com pequena exceção feita ao pensamento organicista alemão de Stein, o modelo fundado no imperialismo napoleónico e concebido e difundido por Bonnin não permitia a menor relação entre a administração pública e a privada. Este corte de relações funda-se não só na origem do Estado nação mas sobretudo no conceito de jus imperium que coloca as partes no contrato em posições muito diferentes. Expressão bem patente do que acabsmos de afirmar está no uso do adjetivo "administrativo" que se junta ao contrato e o diferencia profundamente do contrato comum baseado na igualdade das partes. As leis e a jurisdição administrativa, no início destinada precisamente para proteger o Estado, atiram para polos opostos a administração pública e a privada.

Neste caldo cultural, interrogam-se os autores sobre a introdução de políticas económicas concebidas no seio do paradigma Anglo-saxónico poderem vir a ter sucesso em Portugal sem uma alteração profunda da Constituição da República e uma mudança dramática nos valores que pautam a cultura administrativa de Portugal. 
Em suma, os dois paradigmas permitem fundamentar intervenções muito diferentes do Estado na economia. Na relação Estado/mercado, o paradigma da common law, pelas suas raízes históricas, fará uma aposta mais forte no segundo, ou seja, num menor e melhor Estado, enquanto o modelo europeu continental apostará no primeiro, ou seja, num maior e melhor Estado. Assim, quanto mais bem forem compreendidas as raízes das respetivas administrações públicas, mais se entenderá o tipo e a natureza do papel do Estado na economia.

\section{REFERÊNCIAS}

Allison, Graham T. (1992 [1979]). Public and Private Management: Are They Fundamentally Alike in All Unimportant Respects? In SHAFRITZ, G. M. and HyDE, A. C. (eds.), Classics of Public Administration (pp. 457-474). Belmont, C. A.: Wordsworth.

Araújo, Joaquim Filipe Ferraz Esteves. (2002). nPM and the Change in Portuguese Central Government. International Public Management Journal, vol. 5 (3), pp. 223-236.

Barnard, Chester. (1979 [1938]). As funções do Executivo. São Paulo: Editora Atlas.

BILHIM, J. (2008). Teoria organizacional: estruturas e pessoas. Lisboa: ISCSP.

BiLHim, J. (2014). As práticas dos gestores públicos em Portugal e os Códigos de Ética. Seqüencia, (69), pp. 61-82.

BilHIM, J. (2014). Ciência da Administração, 3. ${ }^{a}$ ed. Lisboa: Universidade Aberta, eUAB, coleção Universitária.

Bonnin, J.C. (1812). Principes d'Administration Publique, 3. ${ }^{a}$ ed. Paris: Renaudiere, Imprimeur-libraire.

Caetano, Marcello (1994). Estudos de História da Administração Pública Portuguesa (organização e prefácio de Freitas do Amaral). Coimbra: Coimbra Editora.

Carvalho, E. (2007). Políticas de Reforma Administrativa em Portugal. Working paper elaborado para o projeto financiado pela FCT "Administração Pública e Competitividade numa Perspetiva Comparada". Lisboa: ISCSP.

Chevalier, J. (1994). Science Administrative, 2. ${ }^{\mathrm{a}}$ ed. Paris: Puf.

Comissão Europeia (2014). EU Anti-Corruption Report [Em linha]. Bruxelas: Comissão Europeia. [Consultado em 13-07-2015]. Disponível em: http://ec.europa.eu/dgs/ home-affairs/what-we-do/policies/organized-crime-and-human-trafficking/corruption/anti-corruption-report/index_en.htm 
Cresap (Comissão de Recrutamento e Seleção para a Administração Pública) - A Cresap [Em linha]. [Consultado em 13-07-2015]. Disponível em: http://www.cresap.pt/

Denhardt, Kathryn G. (1988). The Ethics of Public Service: Resolving Moral Dilemmas in Public Organizations. New York [etc.]: Greenwood Press.

DruCKeR, P. (1995 [1948]). The Practice of Management. Boston: Butterworth Heinemann.

Ferraz, D. (2008). A seleção de dirigentes públicos no contexto da evolução do Estado e da Administração. Contributos para uma definição de uma política integrada. Dissertação de Mestrado em Administração e Políticas Públicas, ISCTE.

Greco (1996). Programme of Action against Corruption [Em linha]. Estrasburgo: Council of Europe. [Consultado em 13-07-2015]. Disponível em: http://www.coe.int/en/ web/portal/google-search/?q=Programme + of + Action + Against + Corruption $\& \mathrm{x}=$ $0 \& \mathrm{y}=0$ \& sitesearch $=$ coe.int

Gregory, R. (2003). All the King's horses and all the King's men: Putting New Zealand's public sector together again. International Public Management Review, vol. 4, (2), pp. 41-58.

Gulick, Luther, URWICK, L. (1937). Papers in the Science of Public Administration. IPA.

Hart, P. T; Wille, A. (2006). Ministers and top officials in the Dutch core executive: Living together, growing apart? Public Administration, vol. 84, (1), pp. 121-146.

Hegel, G. W. F. (1990). Princípios da Filosofia do Direito. Lisboa: Guimarães.

Hood, C. (1995). The "new public management" in the 1980s: Variations on a theme. Accounting, Organizations and Society, vol. 20, (2-3), pp. 93-109.

Kettr, Donald (2000). The Global Public Management Revolution. Washington: Brookings Institution Press.

Kunn, T. (1970). The Structure of Scientific Revolution. Berkeley: University of Chicago Press.

Mozicafredo, J. (2000). O papel do cidadão na Administração Pública, in Reforma do Estado e Administração Pública Gestionária. Lisboa: ISCSP.

Nowell, G. (2009). Public versus private managers: A new perspective. Journal of Business \& Economics Research, v. 7, (3), pp. 1-6.

OCDE (1996). Ethics in the Public Service: Current Issues and Practice. Paris: OCDE [Occasional Paper (14)]. 
OCDE (2000). Trust in Government: Ethics Measures in OECD Countries [Em linha]. Paris: OCDE. [Consultado em 13-07-2015]. Disponível em: http://www.oecd.org/gene$\mathrm{ral} / \mathrm{searchresults} /$ ?q=Trust $\% 20 \mathrm{in} \% 20$ government:\%20ethics $\% 20$ measures $\% 20$ in $\% 20 O E C D \% 20$ countries\&cx $=012432601748511391518$ : $x$ zeadub0b0a $\&$ cof $=F O$ RID:11\&ie $=$ UTF- 8

OCDE (2004). Measures for Promoting Integrity and Preventing Corruption: How to Assess? [Em linha]. Paris: OCDE. [Consultado em 13-07-2015]. Disponível em: http://www.oecd. org/general/searchresults/?q=Measures\%20for\%20promoting \%20integrity \%20 and\%20preventing \%20 corruption:\%20how \%20to\%20assess? \& cx= 01243260174 8511391518:xzeadub0b0a\&cof=FORID:11\&ie $=$ UTF- 8

OCDE (2014). The Rationale for Fighting Corruption [Em linha]. Paris: OCDE. [Consultado em 13-07-2015]. Disponível em: http://www.oecd.org/cleangovbiz/resources.htm

OGE (Office of Government Ethics) - Mission \& Responsibilities [Em linha]. [Consultado em 13-07-2015]. Disponível em: http://www.oge.gov/About/Mission-and-Responsibilities/Mission---Responsibilities/

OLAF (2013). Public Procurement: Costs We Pay for Corruption [Em linha]. Bruxelas: OLAF. [Consultado em 13-07-2015]. Disponível em: http://ec.europa.eu/geninfo/query/index.do ?queryText=Public++Procurement $\% 3 \mathrm{~A}+$ costs+we+pay++for+corruption\&query_so urce $=$ ANTIFRAUD\&summary $=$ summary $\&$ more_options_source $=$ restricted $\&$ more options_date $=* \&$ more_options_date_from $=\&$ more_options_date_to $=\&$ more_op tions_language $=$ en\&more_options_f_formats $=*$ *swlang $=$ en

OlSEN J. P. (1991). Modernization programs in perspective: Institutional analysis of organizational change. Governance, v. 4, (2), pp. 125-49.

Pasquino, G. (2003). Sistemas Políticos Comparados. Cascais: Princípia.

Pedrosa, Guimarães (1908). Curso de Ciência da Administração e de Direito Administrativo. Coimbra: Imprensa da Universidade.

Pollitt, C; Bouckaert, G. (2004). Public Management Reform: A comparative analysis, 2. ed. Oxford: Oxford University Press.

Pollitt, C.; Homburg, V. (2007). The New Public Management in Europe. Palgrave.

Portugal. (2006). Programa de reestruturação da Administração Central do Estado (PRACE). Lisboa: Ministério das Finanças.

RaAdschelders, Jos C. N.; LeE, Kwang-Hoon (2011). Trends in the Study of Public Administration: Empirical and Qualitative Observations from Public Administration Review, 2000-2009. Public Administration Review, vol. 71, (1), January/ February, pp. 19-33. 
Rivero, J. (1980). Doit Administratif, 9. a ed. Paris: Dalloz.

Rosser, C. (2010). Woodrow Wilson's Administrative thought and German Political Theory. Public Administration Review, (4), pp. 547-556.

Rocha, J. (2001). O Modelo Pós-burocrático: A reforma da Administração Pública à luz da experiência internacional recente. In ISCSP (org.), Reforma do Estado e Administração Pública Gestionária. Lisboa: ISCSP, Forum 2000.

Small, A. (2009 [1909]). The Cameralists: The pioneers of German Social Polity. New York: General Books.

SoAres, L. M. P.; Bilhim, J.; NeVES, B. (2005). New ethical challenges in a changing Public Administration [Em linha]. In Ethics and Integrity of Governance: The First Transatlantic Dialogue. Leuven. [Consultado em 13-07-2015]. Disponível em: http://capp. iscsp.ulisboa.pt/publicacoes/e-working-papers-capp

SoAres, L. M. P. (2008). A Ética na Administração Pública, Lisboa: ISCSP.

StiglitZ, Joseph E. (1988). Economics of the Public Sector. London: W.W. Norton Company.

Stillman, R. (1997). American vs. European Public Administration. Public Administration Review, vol. 5 (4), pp. 332-338.

URIBE, V. (s. f.). Preparando "mandarins". file://C:/Users/presidente.CRESAP/ Downloads/19162-62831-1-PB\%20(1).pdf

ViCHER, D. (s. f.). Charles-Jean Bonnin: Transcendencia y resonancia en el mundo. Gobernanza y Gestión Local. Revista de la Licenciatura en Ciencias Políticas y Administración Pública, ano 1, n. ${ }^{\circ}$ 1. http://www.cjbonnin.org/REFERENCIAS/DVicherBonnin. pdf Consultado a 18 de junho, 2015.

Wal, VAn Der ZeGer; GraAf, Gjalt DE; LASthuizen, K. (2008). What's valued most? Similarities and differences between the organizational values of the public and private sector. Public Administration, vol. 86, (2), pp. 465-482. Doi: 10.1111/j.14679299.2008.00719.x

Waldo, D. (1948). The Administrative State: A Study of the Political Theory of American Public Administration. New York: Ronald Press.

Waldo, D. (1955). The Study of Public Administration. New York: Random House.

WALDO, D. (1984). The perdurability of Politics-Administration Dichotomy. In RABIN, JACK; BOWMAN, JAMES S. Politics and Administration. New York: Marcel Dekker, Inc., pp. 219-233. 
Weber M. (1978). Economy and Society. California: University of California City.

WHITE, L. (1926). Introduction to the Study of Public Administration. New York: Macmillan.

Williamson, J. (1990). What Washington means by Policy Reform. In Williamson, J., ed., Latin American Adjustment: How much Has Happened? Washington: Institute for International Economics.

Willoughby (1927). Principles of Public Administration. Washington, D.C.: Brooking Institution.

WiLson, W. (1887). The Study of Public Administration. University of Florida Libraries. (Digitized by the Internet Archive in 2011 with funding from LYRASIS Members and Sloan Foundation). 